\title{
Disinfectant effect of Methylated Ethanol against Listeria species
}

\author{
Y Yakubu*, M D Salihu, O O Faleke, M B Abubakar ${ }^{1}$, A A Magaji and A U J unaidu \\ Dept. of Veterinary Public Health and Preventive Medicine, Faculty of Veterinary Medicine, \\ 1. Dept. of Veterinary Microbiology, Faculty of Veterinary Medicine, \\ Usmanu Danfodiyo University Sokoto, Nigeria. \\ *Corresponding author email: yusufdvm@yahoo.com \\ Received:29-07-2011, Accepted:24-08-2011
}

\begin{abstract}
This study was carried out in order to determine the disinfectant effect of Methylated spirit ${ }^{\circledR}(95 \%$ methanol and 5\% ethanol) as a teat dip against Listeria species. Hand milking was employed to collect $576(288 \times 2)$ raw milk samples from different lactating cows within Sokoto metropolis (Nigeria). 288 samples were collected before disinfecting the udder teats with Methylated spirit ${ }^{\circledR}$, while the other 288 were collected after disinfection with Methylated spirit ${ }^{\circ}$. The samples were analyzed using selective culture and isolation technique in which the 288 samples collected before disinfection, 114 (39.6\%) were positive for Listeria species. Among the positive samples 44 (38.6\%) were Listeria innocua, 16 (14.0\%) Listeria ivanovii, 36 (31.6\%) Listeria monocytogenes, 11 (9.6\%) Listeria welshimeri and 7 (6.1\%) Listeria seeligeri, while none of the 288 samples collected after disinfection was positive. The study has shown high prevalence of Listeria species in milk collected without washing/disinfecting the teats and has also established the sensitivity of Listeria species to methylated ethanol which can be used as dip for disinfecting udder teats before milking in order to prevent contamination with Listeria species and other methylated spirit-sensitive organisms. This study is essential to educate Fulani herdsmen and other milk handlers on the importance of disinfecting udder teats before milking.

Key words: Raw milk, Disinfection, Methylated ethanol, Listeria monocytogenes, Public health
\end{abstract}

\section{To cite this article :}

Yakubu Y, Salihu MD, Faleke OO, Abubakar MB, Magaji AA and Junaidu AU (2012): Disinfectant effect of methylated ethanol against Listeria species, Vet. World 5 (2): 91-93, doi: 10.5455/vetworld.2012.91-93

\section{Introduction}

Listeria monocytogenes is the major cause of listeriosis in both man and animals (Jemmi and Stephan, 2006). The organism has cosmopolitan distribution in the environment and within the gut of animals worldwide (OIE, 2005) and unsanitary practices during slaughtering and milking processes are the main causes of Listeria contamination (Schchat et al., 1991). Products such as raw milk, raw meat products and vegetables are often contaminated with the organism and serve as vehicles of transmission (Johansson et al., 1999).

Other Listeria species include Listeria ivanovii, Listeria innocua, Listeria welshimeri, Listeria seeligeri and Listeria grayi (Jemmi and Stephan, 2006). But only L. monocytogenes is consistently associated with human illness of which Listeria monocytogenes serotype $4 \mathrm{~b}$ strains are responsible for 33 to 50 percent of sporadic human cases worldwide and for all major food borne outbreaks in Europe and North America since the 1980s (Ward et al., 2004). Listeriosis is usually a serious problem in immunocompromised individuals such as pregnant women, infants, geriatrics, HIV or AIDS patients, etc (Acha and Szyfres, 2003). Pregnant women may experience abortion, stillbirth, premature birth and septicemia in the newborn (Acha and Szyfres, 2003). In the elderly, L. monocytogenes causes meningitis, meningoencephalitis or, less frequently, septicaemia (Acha and Szyfres, 2003). While in healthy individuals, the organism causes a syndrome called febrile gastroentitis (Salamina, 
Disinfectant effect of Methylated Ethanol against Listeria species

Table-1: I solation rates of Listeria species before and after disinfection with Methylated spirit ${ }^{\circledR}$

\begin{tabular}{lccc}
\hline Particulars & Number Positive & Number Negative & Total \\
\hline Before Disinfection & 114 & 174 & 288 \\
After Disinfection & 0 & 288 & 288 \\
Total & 114 & 462 & 576 \\
\hline
\end{tabular}

Chi Square-test $=139.65, \mathrm{p}<0.05$

1996). Methylated spirit $®$ (95\% methanol and $5 \%$ ethanol) was chosen for trial in this study owing to its availability, accessibility and affordability to both urban and rural dwellers in Nigeria.

\section{Materials and Methods}

Study design and sample collection : A crosssectional study was conducted within Sokoto metropolis (Nigeria) and a total of 288 samples in duplicates (two each from an animal) were collected from lactating cows in farms and Fulani herds. The first 288 samples were collected before disinfecting the udder teats with Methylated spirit ${ }^{\circledR}$ while the other 288 were collected after disinfecting the teats with Methylated spirit@. A minimum of $30 \mathrm{ml}$ each of the samples was collected in a sterile capped glass bottles and were conveyed in an ice-packed container to the Public Health Laboratory of the Usmanu Danfodiyo University Sokoto, Nigeria.

Culture and identification : Using culture and identification method as recommended by the International Organization for Standardization (ISO 11290-1, 1996), 25ml of each sample was enriched using $225 \mathrm{ml}$ of ONE Broth-Listeria (Oxoid CM1066 \& SR0234) and incubated aerobically at $30^{\circ} \mathrm{C}$ for 48 hours. The brothenriched sample was inoculated onto Oxoid Brilliance Listeria selective differential media (Oxoid SR0227 and SR0228); 0.1ml of the broth was plated and incubated aerobically at $37^{\circ} \mathrm{C}$ for 24hours. Blue-green colonies on the media that expressed gram positive coccobacilli on gram staining were presumed to be Listeria species.

Biochemical Differentiation: Biochemical characterization using catalase, xylose, rhamnose and CAMP tests were further carried out in order to differentiate the various Listeria species.

Statistical Analysis : Chi square test was used to analyze for any significant difference in the occurrence of the organisms in milk samples collected before disinfection and in samples collected after disinfection.

\section{Results}

Out of the 288 samples collected before disinfecting the udder teats, 114 (39.6\%) were positive for Listeria species and none of the corresponding samples collected after disinfection was positive. Upon characterization of the isolates from the positive samples $44(38.6 \%)$ were Listeria innocua, 16(14.0\%) Listeria ivanovii, 36 (31.6\%) Listeria monocytogenes, 11 (9.6\%) Listeria welshimeri and 7 (6.1\%) Listeria seeligeri. The most common isolates were Listeria innocua while the least isolates were Listeria seeligeri.

Statistical analysis showed significant difference in the occurrence of the organisms in milk samples collected before disinfection and in samples collected after disinfection (Chi Squaretest $=139.65, \mathrm{p}<0.05)$.

\section{Discussion}

The study showed that Listeria species particularly Listeria monocytogenes, which is of public health concern could be found in raw milk on sale within Sokoto metropolis. The presence of these organisms in raw milk may be as a result of contamination from the udder teat during milking. More so, the organisms have not been isolated from samples collected after disinfection, which suggests that Listeria species are susceptible to Methylated spirit $\AA$ and can therefore be used as an effective teat disinfectant before milking. The prevalence of Listeria monocytogenes in this study is $31.6 \%$, which is higher than the findings of Emek et al. (2011) that recorded $4 \%$ in raw milk samples from Turkey and Hamdi et al. (2006), who reported a prevalence of $7.7 \%$ in 
Algeria. The high prevalence recorded in this study could be attributed to the unhygienic milking habit in the study area where the udder teats are not being disinfected before milking. Moreover, Statistical analysis showed significant difference in the occurrence of the organisms in milk samples collected before disinfection and in samples collected after disinfection $(\mathrm{p}<0.05)$.

In conclusion, the high prevalence of Listeria monocytogenes in raw milk samples collected without disinfection and its absence in samples collected after disinfection suggests that the organisms are sensitive to Methylated spirit ${ }^{\circledR}$. Moreover, the study shows that Listeria organisms could be present in raw milk on sale within Sokoto metropolis, which is of public health concern as it poses a serious threat to the health of the populace. There is therefore the need for extension personnel to educate the Fulani and other milk handlers the significance of good hygiene such as hand washing and disinfecting udder teats before milking. There is also the need to explore the possible effect of methylated spirit on the quality of milk collected when used as a disinfectant.

\section{Acknowledgements}

We wish to acknowledge the technical advice given by the Head of Department of Public Health and Preventive Medicine and the financial support given by the Management of the Usmanu Danfodiyo University Sokoto, Nigeria.

\section{Conflict of interest}

Authors declare that they have no conflict of interest

\section{References}

1. Acha, P. N. and Szyfres B. (2003). Zoonoses and communicable diseases common to man and animals. In: Bacterioses and mycoses. Pan American Health Organization (PAHO) Scientific and Technical Publication, 3rd ed. Washington DC: No. 580, 168-179pp.

2. Emek D., Ghassan I., Serkan I., Funda B., Yakut O., Tolga K., Sevgi E. and Osman Y. (2011).
Determining existance and antibiotic susceptibility status of Listetia monocytogenes isolated from dairy products, serological and molecular typing of the isolates. Kafkas Univ Vet Fak Derg.17(SuppIA): S11-S119.

3. Hamdi, T.M., Naïm, M., Martin, P. and Jacquet, C.(2006).Identification and molecular characterization of Listeria monocytogenes isolated in raw milk in the region of Algiers (Algeria). International Journal of Food Microbiology 116,190-193.

4. ISO 11290-1 (1996). Microbiology of food and animal feeding stuffs-Horizontal method of detection and enumeration of Listeria monocytogenes, Part I: Detection method.

5. Jemmi, J. and Stephan, R. (2006). Listeria monocytogenes: food-borne pathogen and hygiene indicator. Review Science and Technology, office Intenational Epizootics. 25(2): 571-580.

6. Johansson, T., Rantala, L., Palmu, L. and Honkanen-Bulzalski, T. (1999). Occurrence and typing of Listeria monocytogenes strains in retail vaccum-packed fish products and in a production plant. International Journal of Food Microbiogy, 47: 111-119.

7. Salamina, G., Dalle-Donna, E., Niccolini, A., Poda, G., Cesaroni, D., Bucci, M., Fini, R.,Maldini, M., Schuchat, A., Swaminathan, B., Bibb, W., Rocourt, J., Binkin, N. and Salmaso, S. (1996). A foodborne outbreak of gastroenteritis involving Listeria monocytogenes. Journal of Epidemiology and Infections 117: 429-436.

8. Schchat, A., Swaminathan, B. and Broome, C.V. (1991). Epidemiology of human Listeriosis. Clinical Microbiology Review 4: 169-183.

9. Ward, T. J., Gorski, L., Borucki, M.K., Mandrell, R.E., Hutchins, J. and Pupedis, K. (2004). Intraspecific phylogeny and lineage group identification based on the prfA virulence gene cluster of Listeria monocytogenes. Journal of Bacteriology 186: 4994-5002.

10. World Organisation for Animal Health (Office International des Épizooties: OIE) (2005). Listeriasis, Listerellosis, Circling disease. Institute for International Cooperation in Animal Biologics, Center for Food Security and Public Health, Iowa State University. Available at www.cfsph.iastate.edu/Factsheets/pdfs/ listeriosis.pdf. 